\title{
Pengaruh Edukasi Menggunakan Booklet Terhadap Pengetahuan Orang Tua Dalam Merawat Anak Overweight Dan Obesitas Di Sekolah Dasar Negeri Wilayah Kerja Puskesmas Depok li Kabupaten Sleman Yogyakarta
}

\author{
Liza Putri ${ }^{1}$, Lely Lusmilasari ${ }^{2}$, Fitri Haryanti ${ }^{3}$ \\ Sekolah Tinggi Ilmu Kesehatan Sapta Bakti Bengkulu \\ Email: Lizaputri7@yahoo.co.id
}

\begin{abstract}
ABSTRAK
Data hasil Riset Kesehatan Dasar dari tahun 2010-2013 angka prevalensi overweight dan obesitas pada anak usia 5-12 tahun di DIY mengalami peningkatan, di tahun 2010 terdapat overweight mencapai angka 9,2\% dan pada tahun 2013 menjadi 10,8\% sedangkan, obesitas tahun 2010 mencapai angka 7,8\%, dan di tahun 2013 obesitas mencapai 8,8\% (Balitbangkes RI, 2014). Kabupaten di Provinsi DIY dengan prevalensi overweight dan obesitas yang masih tinggi di Kabupaten Sleman sebesar 4,9\%. Berdasarkan studi pendahuluan di dinas kesehatan dari 17 Puskesmas yang berada di Kabupaten Sleman, jumlah anak yang mengalami overweight dan obesitas tertinggi terdapat di Puskesmas Depok II mencapai angka 321 anak. Penelitian ini merupakan penelitian kuantitatif dengan metode penelitian quasi experimental design dengan rancangan nonrandomized control group pre test post test. Responden adalah ayah/ibu dari anak overweight dan obesitas yang di dua Sekolah Dasar Negeri di Wilayah Kerja Puskesmas Depok II Kabupaten Sleman DIY berjumlah 34 orang untuk masing-masing kelompok. Pengumpulan data menggunakan kuesioner. Edukasi menggunakan media booklet dan Slide. Karakteristik responden berdasarkan umur, pendidikan, pendapatan, pengalaman dan informasi sebelumnya adalah homogen. Berdasarkan hasil penelitian ini gambaran tingkat pengetahuan didapatkan dua kelompok perlakukan sudah mengerti penyebab dari overweight dan obesitas, frekuensi tidur yang baik bagi anak, orangtua mengetahui konsumsi makanan yang baik bagi anak dan aktifitas fisik yang dapat dilakukan. Hasil post test antara kelompok intervensi dan kontrol terdapat perbedaan yang bermakna pada rata-rata nilai pengetahuan $(p=0,005)$. Rata-rata peningkatan nilai pengetahuan antara kelompok intervensi dan kontrol menunjukkan perbedaan yang bermakna $(p<0,05)$. Edukasi menggunakan media booklet berpengaruh terhadap peningkatan pengetahuan orangtua dalam merawat anak overweight dan obesitas.
\end{abstract}

Kata Kunci : Edukasi menggunakan booklet, anak overweight dan obesitas, pengetahuan orangtua

\begin{abstract}
Data from the results of Basic Health Research from 2010-2013 the prevalence of overweight and obesity in children aged 5-12 years in DIY has increased, in 2010 there was overweight reaching 9.2\% and in 2013 to 10.8\% whereas, obesity in 2010 it reached $7.8 \%$, and in 2013 obesity reached 8.8\% (Indonesian Research and Development Agency, 2014). Regencies in DIY Province with high prevalence of overweight and obesity in Sleman Regency are $4.9 \%$. Based on preliminary studies in the health department of 17 Puskesmas in Sleman Regency, the highest number of children who are overweight and obese is in Puskesmas Depok II reaching 321 children. This research is a quantitative study with a quasi experimental design research method with a nonrandomized control group pre test post test design. Respondents are fathers / mothers of overweight and obese children in 34 Public Elementary Schools in Depok II Public Health Center, http://ejournal.urindo.ac.id/index.php/kesehatan
\end{abstract}

Article History :

Sumbitted 15 Juni 2020, Accepted 29 Juni 2020, Published 30 Juni 2020 
Sleman Regency, totaling 34 people for each group. Data collection using a questionnaire. Education using booklet and slide media. Respondent characteristics based on age, education, income, experience and previous information are homogeneous. Based on the results of this study illustrates the level of knowledge obtained by two treatment groups who already understand the causes of overweight and obesity, good sleep frequency for children, parents know that good food consumption for children and physical activity that can be done. Post-test results between the intervention and control groups were significant differences in the average value of knowledge ( $p$ $=0.005)$. The average increase in the value of knowledge between the intervention and control groups showed a significant difference $(p<0.05)$. Education using media booklets has an effect on increasing parents' knowledge in caring for overweight and obese children.

Keywords: Education using booklets, overweight and obese children, parental knowledge

\section{PENDAHULUAN}

Di seluruh dunia prevalensi overweight dan obesitas anak meningkat dari 4,2\% pada tahun 1990 menjadi 6,7\% pada tahun 2010. Tren ini diperkirakan akan mencapai 9,1\% atau 60 juta, pada tahun 2020. Menurut WHO pada tahun 2011 lebih 40 miliar anak dengan umur dibawah 15 tahun mengalami overweight dan obesitas. Permasalah overweight dan obesitas telah menjadi masalah bagi negara berkembang mencapai angka 30 juta anak dan 10 juta terdapat di negara maju. Overweight dan obesitas merupakan penyebab kematian nomor lima di dunia (WHO, 2013).

Data hasil Riset Kesehatan Dasar dari tahun 2010-2013 angka prevalensi overweight dan obesitas pada anak usia 5-12 tahun di DIY mengalami peningkatan, di tahun 2010 terdapat overweight mencapai angka 9,2\% dan pada tahun 2013 menjadi 10,8\% sedangkan, obesitas tahun 2010 mencapai angka 7,8\%, dan di tahun 2013 obesitas mencapai 8,8\% (Balitbangkes RI, 2014). Kabupaten di Provinsi DIY dengan prevalensi overweight dan obesitas yang masih tinggi di Kabupaten Sleman sebesar 4,9\%. Berdasarkan hasil study pendahuluan di dinas kesehatan dari 17 Puskesmas yang berada di Kabupaten Sleman, jumlah anak yang mengalami overweight dan obesitas tertinggi terdapat di Puskesmas Depok II mencapai angka 321anak.

Dari hasil wawancara dengan lima perwakilan orangtua mengenai pengetahuan orangtua tentang overweight dan obesitas, sebagian orangtua belum mengerti secara jelas perbedaan overweight dan obesitas, dampak dari overweight dan obesitas, dan cara merawat anak overweight dan obesitas usia 7-12 tahun.

\section{METODE}

Penelitian ini bertujuan untuk mengetahui pengaruh edukasi menggunakan booklet terhadap pengetahuan orang tua dalam merawat anak mengalami obesitas dan

http://ejournal.urindo.ac.id/index.php/kesehatan 
overweight di Sekolah Dasar Negeri

Yogyakarta. Penelitian ini merupakan penelitian kuantitatif dengan metode penelitian quasi experimental design dengan rancangan nonrandomized control group pre test post test. Responden adalah ayah/ ibu dari anak overweight dan obesitas yang di dua Sekolah Dasar Negeri di Wilayah Kerja Puskesmas Depok II Kabupaten Sleman DIY berjumlah 34 orang untuk masingmasing kelompok. Pengumpulan data menggunakan kuesioner. Edukasi menggunakan media booklet dan Slide.

\section{PENGUKURAN}

Penelitian ini dilakukan setelah menerima ethical Committee Approval dari Komisi Etik
Fakultas Kedokteran Universitas Gadjah Mada (Ref: /FK/0420/EC/2017). Pengumpulan data dilakukan dengan menggunakan kuesioner dari penelitian Erika et al., (2016) yang di isi oleh masing-masing responden dengan durasi pengisian kuesioner 25 menit. Peneliti juga meminta responden untuk menandatangani lembar informed consent sebagai bukti kesediaan responden untuk terlibat dalam penelitian ini. Data yang telah terkumpul di analisis dengan menggunakan uji $T$ test independent untuk melihat perbandingan pre-post test dan analisis korelasi spearman untuk melihat karakteristi responden dengan hubungan pengetahuan.

\section{HASIL PENELITIAN}

Tabel.1 Distribusi dan Frekuensi Responden Menurut Umur, Pendidikan, Pendapatan, dan Informasi Orangtua di dua SD Negeri di Sleman Yogyakarta Bulan Mei - Juni 2017 (n=34)

\begin{tabular}{|c|c|c|c|c|c|}
\hline \multirow[t]{2}{*}{ Variabel } & \multicolumn{2}{|c|}{ Kontrol } & \multicolumn{2}{|c|}{ Intervensi } & \multirow[t]{2}{*}{ P Value } \\
\hline & $\mathbf{F}$ & $\%$ & $f$ & $\%$ & \\
\hline \multicolumn{6}{|l|}{ Status Gizi Anak } \\
\hline - Overweight & 6 & 17,6 & 20 & 58,8 & 0,01 \\
\hline - Obesitas & 28 & 82,4 & 14 & 41,2 & \\
\hline \multicolumn{6}{|c|}{ Jenis kelamin responden } \\
\hline - laki-laki & 8 & 23,5 & 3 & 8,8 & 0,100 \\
\hline - perempuan & 26 & 76,5 & 31 & 91,2 & \\
\hline Umur & & & & & 0,223 \\
\hline 20-40 tahun & 13 & 38,2 & 18 & 52,9 & \\
\hline
\end{tabular}




\begin{tabular}{lccccc}
$>40$ tahun & 21 & 61,8 & 16 & 47,1 & \\
$\begin{array}{l}\text { Pendidikan } \\
\text { - Dasar }\end{array}$ & 9 & 26,5 & 6 & 17,6 & 0,283 \\
- Menengah & 17 & 50 & 14 & 41,2 & \\
- Tinggi & 8 & 23,5 & 14 & 41,2 & \\
$\begin{array}{l}\text { Pendapatan } \\
\text { - Rendah }\end{array}$ & 27 & 79,4 & 24 & 70,6 & 0,401 \\
- Tinggi & 7 & 20,6 & 10 & 29,4 & \\
Mendapatkan informasi & & & & & \\
terkait overweight dan & & & & & \\
obesitas & & & & & \\
- Pernah & 21 & 61,8 & 26 & 76,5 & 0,189 \\
- Tidak pernah & 13 & 38,2 & 8 & 23,5 & \\
\hline
\end{tabular}

Uji normalitas ini menunjukkan bahwa tidak terdapat perbedaan untuk jenis kelamin, umur, pendidikan, pendapatan dan media informasi antara kelompok perlakuan dan kelompok kontrol.

Tabel .2 Pengetahuan (pre-test-post-test) Responden Berdasarkan Distribusi Jawaban Pada Kelompok Intervensi $(n=34)$

\begin{tabular}{|c|c|c|c|c|c|c|}
\hline \multirow[t]{3}{*}{ Dimensi } & \multirow[t]{3}{*}{ Sub dimensi } & \multirow[t]{3}{*}{ No } & \multicolumn{4}{|c|}{ Pilihan Jawaban } \\
\hline & & & \multicolumn{2}{|c|}{ Sebelum edukasi } & \multicolumn{2}{|c|}{ Setelah edukasi } \\
\hline & & & B & $\mathrm{S}$ & B & $\mathrm{S}$ \\
\hline & & & $\mathrm{n}(\%)$ & $\mathrm{n}(\%)$ & $\mathrm{n}(\%)$ & $\mathrm{n}(\%)$ \\
\hline \multirow[t]{3}{*}{ Dimensi I } & Definisi anak & 1 & $12(35)$ & $22(65)$ & $29(85)$ & $5(15)$ \\
\hline & overweight & 6 & $8(23)$ & 26 (77) & $30(88)$ & $4(12)$ \\
\hline & dan obesitas & 10 & $8(23)$ & $26(77)$ & $27(79)$ & $7(21)$ \\
\hline \multirow[t]{3}{*}{ Dimensi II } & Penyebab & 5 & $33(97)$ & $1(3)$ & $34(100)$ & $0(0)$ \\
\hline & anak & 20 & $28(82)$ & $6(18)$ & $31(91)$ & $3(9)$ \\
\hline & $\begin{array}{l}\text { overweight } \\
\text { dan obesitas }\end{array}$ & 22 & $23(67)$ & $11(33)$ & $30(88)$ & $4(12)$ \\
\hline \multirow[t]{3}{*}{ Dimensi III } & Akibat anak & 8 & $18(53)$ & $16(47)$ & $23(68)$ & $11(32)$ \\
\hline & overweight & 11 & $24(70)$ & $10(30)$ & $23(68)$ & $11(32)$ \\
\hline & dan obesitas & 23 & $24(70)$ & $10(30)$ & $28(82)$ & $6(18)$ \\
\hline
\end{tabular}




\begin{tabular}{|c|c|c|c|c|c|c|}
\hline \multirow[t]{16}{*}{ Dimensi IV } & \multirow{4}{*}{$\begin{array}{l}\text { Merawat } \\
\text { anak } \\
\text { overweight } \\
\text { dan obesitas }\end{array}$} & 2 & $7(20)$ & $27(80)$ & $23(68)$ & $11(32)$ \\
\hline & & 3 & $21(62)$ & $13(38)$ & 34 (100) & $0(0)$ \\
\hline & & 4 & $28(82)$ & $6(18)$ & $27(79)$ & $7(21)$ \\
\hline & & 7 & $16(47)$ & $18(53)$ & $32(94)$ & $2(6)$ \\
\hline & & 9 & $14(41)$ & $20(59)$ & $20(58)$ & $14(42)$ \\
\hline & & 12 & $32(94)$ & $2(6)$ & 34 (100) & $0(0)$ \\
\hline & & 13 & $22(65)$ & $12(35)$ & $24(70)$ & $10(30)$ \\
\hline & & 14 & $34(100)$ & $0(0)$ & $34(100)$ & $0(0)$ \\
\hline & & 15 & $29(85)$ & $5(15)$ & $32(94)$ & $2(6)$ \\
\hline & & 16 & 27 (79) & $7(21)$ & $31(91)$ & $3(9)$ \\
\hline & & 17 & $24(71)$ & $10(29)$ & $20(58)$ & $14(42)$ \\
\hline & & 18 & $28(82)$ & $6(18)$ & $30(88)$ & $4(12)$ \\
\hline & & 19 & $24(70)$ & $10(30)$ & $26(76)$ & $8(24)$ \\
\hline & & 21 & 33 (97) & $1(3)$ & $34(100)$ & $0(0)$ \\
\hline & & 24 & $24(70)$ & $10(30)$ & $24(70)$ & $10(30)$ \\
\hline & & 25 & $25(74)$ & $9(26)$ & $32(94)$ & $2(6)$ \\
\hline
\end{tabular}

Tabel diatas menunjukkan bahwa kelompok intervensi sebelum diberikan edukasi, dimensi pengetahuan tertinggi yang dijawab responden terdapat pada dimensi IV, pada sub dimensi nomor 14 "merawat overweight dan obesitas pada anak usia 7-12 tahun" dengan jumlah 34 responden atau sebesar $100 \%$ responden menjawab dengan benar. Sedangkan setelah edukasi, dimensi pengetahuan tertinggi yang dijawab responden terdapat pada dimensi II pada sub dimensi nomor 5 "penyebab overweight dan obesitas pada anak usia 7-12 tahun",dan dimensi IV pada sub dimensi nomor $3,12,14,21$ "merawat overweight dan obesitas anak usia 7-12 tahun" dengan jumlah 34 responden, dari total jumlah 34 responden, sebesar $100 \%$ responden menjawab dengan benar.

Tabel .3 Pengetahuan (pre-test-post-test) Responden Berdasarkan Distribusi Jawaban Pada Kelompok Kontrol $(n=34)$

\begin{tabular}{|c|c|c|c|c|c|c|}
\hline \multirow[t]{3}{*}{ Dimensi } & \multirow[t]{3}{*}{ Sub dimensi } & \multirow[t]{3}{*}{ No } & \multicolumn{4}{|c|}{ Pilihan Jawaban } \\
\hline & & & \multicolumn{2}{|c|}{ Sebelum edukasi } & \multicolumn{2}{|c|}{ Setelah edukasi } \\
\hline & & & B & $S$ & B & $S$ \\
\hline & & & $\mathrm{n}(\%)$ & $\mathrm{n}(\%)$ & $\mathrm{n}(\%)$ & $\mathrm{n}(\%)$ \\
\hline \multirow[t]{3}{*}{ Dimensi I } & Definisi & 1 & $8(23)$ & $26(77)$ & $20(59)$ & $14(41)$ \\
\hline & overweight & 6 & $17(50)$ & $17(50)$ & $26(76)$ & $8(24)$ \\
\hline & dan obesitas & 10 & $6(18)$ & $28(82)$ & $23(77)$ & $11(23)$ \\
\hline \multirow[t]{2}{*}{ Dimensi II } & Penyebab & 5 & $33(97)$ & $1(3)$ & $34(100)$ & $0(0)$ \\
\hline & anak & 20 & $23(68)$ & $11(32)$ & $29(85)$ & $5(15)$ \\
\hline
\end{tabular}




\begin{tabular}{llccccc} 
& $\begin{array}{l}\text { overweight } \\
\text { dan obesitas }\end{array}$ & 22 & $30(88)$ & $4(12)$ & $23(68)$ & $11(32)$ \\
Dimensi III & $\begin{array}{c}\text { Akibat anak } \\
\text { overweight }\end{array}$ & 8 & $21(62)$ & $13(38)$ & $15(44)$ & $19(56)$ \\
& 11 & $25(73)$ & $9(27)$ & $21(62)$ & $13(38)$ \\
dan obesitas & 23 & $24(70)$ & $10(30)$ & $19(56)$ & $15(44)$ \\
& Merawat anak & 2 & $2(5)$ & $32(95)$ & $5(15)$ & $29(85)$ \\
& overweight & 3 & $20(58)$ & $14(42)$ & $25(73)$ & $9(27)$ \\
& dan obesitas & 4 & $30(88)$ & $4(12)$ & $24(70)$ & $10(30)$ \\
& 7 & $20(58)$ & $14(42)$ & $27(79)$ & $7(21)$ \\
& 9 & $13(38)$ & $21(62)$ & $12(35)$ & $22(65)$ \\
& 12 & $32(94)$ & $2(6)$ & $30(88)$ & $4(12)$ \\
& 13 & $13(38)$ & $21(62)$ & $15(44)$ & $19(56)$ \\
& 14 & $32(94)$ & $2(6)$ & $34(100)$ & $0(0)$ \\
& 15 & $30(88)$ & $4(12)$ & $30(88)$ & $4(12)$ \\
& 16 & $22(65)$ & $12(35)$ & $25(73)$ & $9(27)$ \\
& 17 & $13(38)$ & $21(62)$ & $13(38)$ & $23(62)$ \\
& 18 & $23(68)$ & $11(32)$ & $34(100)$ & $0(0)$ \\
& 19 & $25(73)$ & $9(27)$ & $10(29)$ & $24(71)$ \\
& 21 & $30(88)$ & $4(12)$ & $34(100)$ & $0(0)$ \\
& 24 & $24(70)$ & $10(30)$ & $22(65)$ & $12(35)$ \\
& 25 & $20(58)$ & $14(42)$ & $25(73)$ & $9(27)$ \\
\hline
\end{tabular}

\begin{abstract}
Tabel diatas menunjukkan bahwa kelompok kontrol sebelum diberikan edukasi, dimensi pengetahuan tertinggi yang dijawab responden terdapat pada dimensi II, pada sub dimensi nomor 5 "penyebab anak overweight dan obesitas pada anak usia 7-12 tahun" dengan jumlah 33 responden, dari total jumlah 34 responden, sebesar $97 \%$ responden menjawab dengan benar. Sedangkan setelah edukasi pada kelompok kontrol
\end{abstract}

dimensi pengetahuan tertinggi yang dijawab responden terdapat pada dimensi II dengan sub dimensi "penyebab anak overweight dan obesitas pada anak usia 7-12 tahun" pada nomor 5 dan dimensi IV dengan sub dimensi nomor 14,18,21 "merawat anak overweight dan obesitas usia 7-12 tahun" dengan jumlah responden 34, dari total jumlah 34 responden, sebesar $100 \%$ responden menjawab dengan benar. 
Tabel. 4 Perbedaan Rata-rata Selisih Nilai Pengetahuan Responden di Sekolah Dasar Negeri Bhakti Karya dan Condong Catur bulan Mei-Juni 2017 ( $n=34)$

\begin{tabular}{|c|c|c|c|c|c|}
\hline \multirow[t]{2}{*}{ Kelompok } & Pre-test & Post test 1 & Post test 2 & \multirow{2}{*}{$\begin{array}{l}\text { Selisih } \\
\text { pre-post } \\
\text { test } 2\end{array}$} & \multirow[t]{2}{*}{ P value } \\
\hline & & Mean \pm SD & & & \\
\hline Intervensi & $62,00 \pm 12,42$ & $78,05 \pm 11,40$ & $82,47 \pm 09,30$ & 20,47 & \\
\hline Kontrol & $59,17 \pm 13,59$ & $74,41 \pm 11,75$ & $70,11 \pm 10,43$ & 10,94 & 0,005 \\
\hline
\end{tabular}

Hasil analisis uji statistik peningkatan yang signifikan antara ratadidapatkan nilai pre-post test $2 \mathrm{p}=$ rata nilai pengetahuan kelompok 0,005, berarti terlihat ada perbedaan intervensi dan kelompok kontrol.

Tabel. 5 Hubungan Variabel Luar dengan Pengetahuan Orangtua Pada Kelompok Intervensi dan Kelompok Kontrol Setelah Dilakukan Edukasi di Sekolah Dasar Negeri Condong Catur Dan Bhakti Karya Wilayah Kerja Puskesmas Depok II Kab, Sleman

\begin{tabular}{lcc}
\multicolumn{3}{c}{ Yogyakarta $(\mathrm{n}=34)$} \\
\hline Variabel & $\mathrm{r}$ & $\mathrm{P}$ \\
\hline Umur & $-0,194$ & 0,113 \\
Pendidikan & 0,563 & 0,000 \\
Pendapatan & 0,429 & 0,000 \\
Media Informasi & $-0,407$ & 0,001 \\
\hline
\end{tabular}

Berdasarkan tabel di atas, dapat di ketahui bahwa variabel umur tidak memiliki hubungan signifikan dan variabel pendidikan, pendapatan, media informasi ada hubungan signifikan antara karakteristik responden dengan pengetahuan orangtua dengan nilai $p<0,05$.

Tabel. 6 Hasil Analisis Multivariat $(n=34)$

\begin{tabular}{cccc}
\hline Variabel & Koefesien Regresi & $\mathrm{p}$ & $\mathrm{Cl} 95 \%$ \\
\hline Edukasi & 9,75 & 0,000 & $5,71-13,89$ \\
Umur & -865 & 0,675 & $-4,96-3,23$ \\
Pendidikan & 5,23 & 0,005 & $1,66-8,81$ \\
Pendapatan & 1,54 & 0,369 & $-1,87-4,96$ \\
Media Informasi & $-4,91$ & 0,039 & $-4,96--250$ \\
\hline
\end{tabular}


Pada tabel di atas didapatkan hasil bahwa variabel edukasi merupakan variabel yang paling erat hubungannya terhadap pengetahuan orangtua dibandingkan dengan variabel lainnya (usia, pendidikan, pendapatan, dan media informasi).

\section{PEMBAHASAN}

\section{Gambaran Pengetahuan Responden} tentang Merawat Anak Overweight dan Obesitas

Dimensi tertinggi pengetahuan responden pada kelompok intervensi sebelum diberikan edukasi berada pada dimensi IV tentang merawat anak overweight dan obesitas pada anak usia 7-12 tahun, setelah diberikan edukasi pengetahuan responden tertinggi berada pada dimensi II tentang penyebab anak overweight dan obesitas dan dimensi IV tentang merawat anak overweight dan obesitas.

$$
\text { Pada kelompok kontrol }
$$
pengetahuan responden tertinggi pada dimensi II tentang penyebab overweight dan obesitas, setelah diberikan edukasi pengetahuan responden tertinggi berada pada dimensi II tentang penyebab overweight dan obesitas dan dimensi IV tentang merawat overweight dan obesitas anak usia 7-12 tahun.

Sebagian orangtua sudah memahami penyebab dan cara merawat anak overweight dan obesitas. Menurut Mustaq et al., (2011) penyebab anak overweight dan obesitas karena kurangnya aktifitas fisik yang dilakukan dan gaya hidup yang tidak sehat(sedentary life). Dengan adanya edukasi gizi dilakukan dapat meningkatkan pengetahuan orang tua tentang pemberian makan dan kegiatan fisik yang dapat dilakukan, yang akhirnya akan berpengaruh pada perilaku anak. sehingga pentingnya pengetahuan yang dimiliki orangtua dalam memberikan informasi atau pendidikan gizi kepada anak-anaknya (Sato,dkk 2010).

\section{Pengaruh Edukasi Terhadap}

\section{Pengetahuan Orangtua Dalam Merawat} anak Overweight dan obesitas

Rata-rata nilai pre- test pengetahuan orangtua pada kelompok intervensi dan kelompok kontrol tidak jauh berbeda. Pada post- test pertama nilai pengetahuan orangtua pada kelompok kontrol dan intervensi mengalami peningkatan. Peningkatan nilai tersebut menunjukkan adanya 
perbedaan yang bermakna pada kelompok intervensi sebelum dan sesudah intervensi. Peningkatan tersebut diartikan sebagai hasil edukasi dengan slide dan pemberian booklet kepada responden. Rata-rata nilai pada kelompok kontrol menunjukkan adanya perbedaan yang bermakna pada sebelum dan sesudah diberikan edukasi, tetapi tidak setinggi pada kelompok intervensi.

Senada dengan penelitian yang dilakukan oleh Goodarzi et al., (2012), juga menunjukkan efektivitas edukasi terhadap pengetahuan. Pengetahuan tentang merawat anak overweight dan obesitas pada kelompok orangtua mengalami peningkatan setelah diberikan edukasi melalui media booklet.

Penelitian ini sejalan dengan penelitian Mintarsih (2007) yang menyatakan bahwa pengetahuan pada kelompok intervensi yang mendapatkan pendidikan kesehatan melalui booklet mengalami peningkatan. Begitupun menurut Arsyad (2011) yang menyatakan pendidikan kesehatan menggunakan media booklet berperan meningkatkan pengetahuan, media ini dapat mengefektifkan proses penyampaian isi materi pengajaran yang diberikan.

Hasil analisis independen $\mathrm{t}$ test untuk melihat perbandingan pengaruh pada kedua kelompok perlakuan setelah diberikan edukasi tentang merawat anak overweight dan obesitas. Skor pengetahuan yang diperoleh masingmasing kelompok menunjukkan bahwa pada kelompok intervensi lebih tinggi dibanding kelompok kontrol ( $p=0,005$, $\alpha=0,05)$. Peningkatan nilai tersebut menunjukkan adanya perbedaan yang bermakna pada kelompok intervensi sebelum dan sesudah intervensi. Peningkatan tersebut diartikan sebagai hasil edukasi dengan booklet dan slide, karena karakteristik awal responden sama. Hasil analisis perbandingan pada penelitian ini menunjukkan bahwa kelompok perpaduan intervensi yang efektif meningkatkan pengetahuan jika dibandingkan dengan kelompok kontrol.

Booklet merupakan panduan untuk orangtua dalam merawat anak overweight dan obesitas. Sejalan dengan peningkatan pengetahuan, maka orangtua diharapkan memiliki kesadaran dan selanjutnya akan bertindak sesuai dengan pengetahuan yang dimilikinya. Senada dengan hasil penelitian Lubis (2013) menunjukkan ada perbedaan rerata nilai pengetahuan respoden sesudah intervensi.

Dalam penelitian ini, edukasi dengan media slide dan booklet 
merupakan stimulus atau objek yang dapat memberi pengaruh pada responden untuk meningkatkan pengetahuan sesuai dengan pesan atau isi dari materi yang disampaikan sehingga responden dapat memutuskan perilaku apa yang akan diambil dimasa depan. responden dalam penelitian ini adalah para orangtua yang mempunyai anak overweight dan obesitas di Sekolah dasar Negeri Bhakti Karya dan Condong Catur Kab, Sleman.

2. Hubungan Variabel Luar (umur, pendidikan, pendapatan dan media informasi) terhadap pengetahuan orangtua dalam merawat anak overwieght dan obesitas.

Berdasarkan hasil penelitian ini, variabel luar seperti pendidikan, pendapatan dan media informasi memiliki hubungan signifikan baik terhadap variabel dependen dan independen. Menurut Menurut Maisaroh (2013), Semakin tinggi dan formal tingkat pendidikan yang dimiliki seseorang maka semakin besar pula tingkat pengetahuan yang bersifat intelektual yang dimiliki seseorang tersebut.

Menurut Khalili et al., (2006) seseorang yang berpendidikan tinggi mempunyai kesadaran dan kebutuhan terhadap informasi semakin baik, sehingga apabila anak overweight dan obesitas akan segera mencari informasi yang dibutuhkan untuk menangani overweight dan obesitas serta segera melakukannya, misalnya dengan memberikan pola hidup sehat dan mengatur aktivitas fisik di rumah.

Pada faktor pendapatan mempengaruhi pengetahuan orangtua $(p<0,05) . \quad$ Menurut Davis (2013); Maisaroh (2013); Febrianto (2012) yang menyebutkan bahwa sebagian besar pendapatan mempengaruhi pengetahuan orangtua. Pernyataan tersebut didukung dari penelitian Nirwana (2012), anak yang memiliki keluarga berlatar belakang pendapatan rendah berisiko lebih besar terjadi obesitas. Karena mereka tidak pernah memperhatikan apakah makanan mereka sehat atau tidak, bagi mereka yang terpenting bisa makan, tidak memprioritaskan makanan yang sehat dan olahraga dalam keluarga yang membutuhkan waktu dan uang. Itulah yang membuat anak-anak mudah terjadi overweight dan obesitas (Nirwana,2012).

Begitu juga dengan penelitian Pakpour et al., (2015); Mellia (2015) yang menyimpulkan bahwa orangtua dari anak overweight dan obesitas sebagian 
besar memiliki pendapatan tinggi perbulan. Pendapatan orangtua yang baik akan membuat terpenuhinya kebutuhan hidup sehari-hari seluruh anggota keluarga. Pendapatan orangtua juga akan menentukan tersedianya fasilitas yang diperlukan untuk kegiatan tertentu sehingga dapat meningkatkan pengetahuan seseorang.

Dari hasil analisis pada variabel informasi didapatkan lebih dari 50\% responden pernah mendapatkan informasi terkait overweight dan obesitas pada anak. hal ini disimpulkan bahwa informasi responden menunjukan hubungan ada signifikan dengan variabel pengetahuan orangtua dalam merawat anak overweight dan obesitas $(p<0,05)$. Menurut Falconer et al., (2014) informasi dapat memberikan pengaruh terhadap peningkatan pengetahuan dalam pencegahan overweight dan obesitas anak. Pada penelitian Mazarello et al.,(2014) mengatakan pengetahuan dapat mempengaruhi terjadi obesitas sehingga diperlukan edukasi sebagai media informasi untuk meningkatkan pengetahuan dan perilaku seseorang.

\section{KESIMPULAN}

1. Edukasi menggunakan media booklet berpengaruh terhadap peningkatan pengetahuan orangtua dalam merawat anak overweight dan obesitas pada usia 7-12 tahun ( $p=0,005, \alpha=0,05)$

2. Tidak ada perbedaan pengetahuan orangtua dalam merawat anak overweight dan obesitas pada kelompok intervensi dan kelompok kontrol (pretest).

3. Terdapat perbedaan peningkatan pengetahuan antara sebelum dan sesudah edukasi pada kelompok intervensi dan kelompok kontrol.

4. Terdapat perbedaan selisih lebih tinggi rata-rata pengetahuan pada kelompok intervensi (edukasi menggunakan media booklet) dari pada kelompok kontrol (edukasi tanpa pemberian booklet).

\section{KETERBATASAN}

\section{KESIMPULAN}

Edukasi menggunakan media booklet berpengaruh terhadap peningkatan pengetahuan orangtua dalam merawat anak overweight dan obesitas.

\section{DAFTAR PUSTAKA}

Almatsier, Sunita. 2007. Prinsip Dasar IImu Gizi. Jakarta: Gramedia

Arikunto, Suharsimi. 2010 . Prosedur Penelitian. Jakarta : Rineka Cipta.

Adisasmito, W., 2007. Faktor risiko diare pada bayi dan balita di Indonesia: 
systematic review penelitian akademik bidang kesehatan masyarakat. Http://repository.ui.ac.id/contents/kol eksi/.

Agustin, M. 2014. Efektifitas Pendidikan Kesehatan Media Booklet Dibandingkan Audiovisual Terhadap Pengetahuan Orangtua Tentang Karies Gigi Pada Anak Usia 5-9 Tahun Di Desa Makam Haji. Skripsi, Universitas Muhamadiyah Surakarta.

Ahmad. 2010. Pengalaman Keluarga Merawat Anak Usia Sekolah dengan Obesitas yang Bersekolah di Sekolah Dasar Kota Yogyakarta: Studi Fenomenologi. Skripsi, Universitas Indonesia, Depok.

Arsyad, A. 2010. Media Pembelajaran. Jakarta: PT. Raja Grafindo Persada.

Andriani, R., Effendy, R., \& Nurhesti, P. 2009. Perbedaan Tingkat Pengetahuan Perawat Pre dan Post Pemberian Booklet Diagnosa Keperawatan dan Masalah Kolaboratif pada Pasien Stroke. Jurnal Ilmu Keperawatan, Vol. $4(3)$.

Balitbangkes RI. 2010. Riset Kesehatan Dasar. Profil Kesehatan Daerah Istimewa Yogyakarta Tahun 2010. Yogyakarta : Dinas Kesehatan DIY

Balitbangkes RI. 2014. Riset Kesehatan Dasar. Profil Kesehatan Daerah Istimewa
Yogyakarta Tahun 2014. Yogyakarta : Dinas Kesehatan DIY

Barr, R. G., Rivara F. P., Barr, M., Cummings, P., Taylor, J., Lengua, L. J. 2009. Effectiveness of educational materials designed to change knowledge and behaviors regarding crying and shaken-baby syndrome in mothers of newborns: a randomized, controlled trial. $h t t p: / / w w w . \quad$ pediatrics. appublication. org/

Baker JL, Olsen LW, Sorensen Tia . 2007. Childhood Body-Mass Index and The Risk of Coronary Heart Disease In Adulthood. NEJM 357: 2329-2337.

Centers for Disease Control and Prevention (CDC). 2012. Overweight and obesity: Basics about childhood obesity. Retrieved from http://www.cdc.gov/obesity/childhood /basics.html.

Carlott Jo, Twycross Alison, 2006. Negotiation of parental roles within family-centred care: a review of the research. Jurnal of Clinical Nursing.

Donggori, Indriana , R. 2012. Hubungan Akses Media Massa Dengan Pengetahuan Kesehatan Reproduksi Pada Remaja. Skripsi, Universitas Diponegoro Surabaya.

Departemen Kesehatan Republik Indonesia. 2010. Laporan Nasional Riset 
Kesehatan Dasar. Jakarta: Pusat penelitian pengembangan kesehatan.

Departemen Kesehatan Republik Indonesia. 2013. Laporan Nasional Riset Kesehatan Dasar. Jakarta: Pusat Penelitian Pengembangan Kesehatan.

Davis AM, James RL. 2014. An In-Home Intervention to Improve Nutrition, Physical Activityand Knowledge among Low-Income Teen Mothers and Their.J Dev Behav Pediatr. doi:10.1097/DBP.0b013e3182a509df.

Dewi, Pujiastuti, Fajar. 2013. IImu Gizi Untuk Praktisi Kesehatan. Yogyakarta : Graha ilmu

Erfandi. 2009. Pengetahuan dan Faktorfaktor Yang Mempengaruhi. http://for betterhealth.wordpress.com.

Emily, E.T.S, \& Tony, N.B. 2010. Evaluating the health belief model : A critical review of studies predicting mammographic and pap screening. Social Theory \& Health, 8,95-125.

Effendi, F \& Makhfudli. 2009. Keperawatan Kesehatan Komunitas: Teori dan Praktek Dalam Keperawatan. Jakarta: Salemba medika

Emilia, O. 2008. Promosi Kesehatan dalam Lingkup Kesehatan Reproduksi. Yogyakarta: Pustaka Cendekia.

Falconer, L.C, Min H.Park, Helen C, Aine S, James B, Sonia S, Anthony, S.K, Saffron
K, Stephen M, Russell, M.V, Sanjay K. 2014. The Benefits And Harms of Providing Parents With Weight Feedback As Part Of The National Child Measurement Programme: A Prospective Cohort Study. BMC Public Health 2014, 14:549

Festy, P. 2012. Hubungan Perilaku Orangtua Dengan Kejadian Obesitas Pada Anak Prasekolah (3-5 Tahun) di Taman Flora Kota Surabaya. Jurnal Akes Rajekwesi Bojonegoro Vol.6.

Febrianto, I. D. 2012. Hubungan Tingkat Penghasilan, Tingkat Pendidikan Dan Tingkat Pengetahuan Orangtua Tentang Makanan Bergizi Dan Status Gizi Siswa Tk Islam Zahrotul Ulum Karang Ampel Indramayu. Skripsi, Universitas Negeri Yogyakart, Yogyakarta.

Faisal,Yatim. 2007. 30 Gangguan Masalah Kesehatan Pada Anak Sekolah. Jakarta: Pustaka Populer Obor.

Goodarzi, M., Ebrahimzadeh, I., Rabi, A., Saedipoor, B., \& Jafarabadi, M. A. 2012. Impact of Distance Education Via Mobile Phone Text Messaging on Knowledge, Attitude, Practice and Self Efficacy of Patients with Type 2 Diabetes Mellitus in Iran. Journal of Diabetes \& Metabolic Disorders, 11(1), 
1-8. http://doi.org/10.1186/22516581-11-10

Galih, T. U. 2012. Pengaruh Latihan Senam Aerobik Terhadap Penurunan Berat Badan, Persen Lemak Tubuh Dan Kadar Kolesterol Pada Remaja Putri Penderita Obesitas Di Sanggar Senam Studio 88 Salatiga. Tesis, Universitas Negeri Semarang

Guo X, Zheng L, Li Y, Yu S, Sun G, Yang H.2012. Differences In Lifestyle Behaviors, Dietary Habits, and Familial Factors Among Normal-Weight, Overweight, and Obese Chinese Children and Adolescents. International Journal of Behavioral Nutrition \& Physical Activity ;9(1):1208

Hartono, S. 2006. Terapi Gizi Dan Diet Rumah Sakit.(ed 2).jakarta:EGC

Hurlock, E. 2004. Psikologi Perkembangan. Jakarta : Erlangga

Hermina, Nurfi Afriansyah, Abas B,Jahari.2008. Efek Intervensi Pendidikan Berbasis-Sekolah Terhadap Tingkat Pengetahuan Tentang Pencegahan Kegemukan di Antara Anak-anak Usia 9-10 Tahun Di Kota Bandung. Laporan Penelitian, Bandung: Pusat Penelitian dan Pengembangan Gizi.
IDAI. 2014. Diagnosis, Tata Laksana dan Pencegahan Obesitas Pada Anakdan Remaja. Jakarta: Ikatan Dokter Anak Indonesia.

Irwan Dwi Febrianto. Hubungan Tingkat Penghasilan, Tingkat Pendidikan Dan Tingkat Pengetahuan Orangtua Tentang Makanan Bergizi Dengan Status Gizi Siswa TK Islam Zahrotul Ulum Karangampel Indramayu. Skripsi, Universitas Negeri Yogyakarta, Yogyakarta.

Ismail D, Herini ES, Hagung P, \& Sadjimin T. 2013. Fast food consumption and obesity: Relationship among elementary school students in Yogyakarta. Paediatrica Indonesian.

KBBI. 2015. Kamus Besar Bahasa Indonesia. Jakarta: Indonesia.

Kemm, J \& Close, A. 1995. Health Promotion Theory and Practice. London Macmillan Press.

Khalili, B, Gorbanali, S, Khalili,M,mardani,M \& Cuevas,L.E. 2006. Risk factor for hospitalization of children with diarrhea in Shahrekord,Iran. Iranian Journal of Clinical infectious Diseases, 1(3),131-136.

Kementerian Kesehatan Republik Indonesia. 2012. Pedoman Pencegahan dan Penanggulanagn Kegemukan dan Obesitas Pada Anak Sekolah. Jakarta: 
Kementerian Kesehatan RI.

Kadek Ayu Erika, Elly Nurachmah, Yeni Rustina, Suryani As'ad and Werna Nontji. 2016. Effect of family empowerment modified model to a family ability in controlling life style and physical activity of children with overweight and obesity. Pakistan Journal of Nutrition 15 (8):737744,2016

Lakshita, A. 2012. Tips Simpel Mencegah Dan Menanggani Obesitas. Jakarta: Java litera.

Liu He, Yi Zhai, Michael E, Weirong Li, Hanzhu Qian, Xiang Si, Xin Gao, Melanie S, Jing L , Xiaolei Z , Xiaoming S. 2013. Association Of Children's Eating Behaviors With Parental Education, And Teachers' Health Awareness, Attitudes And Behaviors: ANational School-Based Survey In China. European Journal of Public Health, Vol. 24, No. 6, 880-887

Moch. Dwi Cahyo Saputro. 2014. Hubungan Antara Tingkat Pendidikan Orangtua Dengan Status Gizi Siswa (Studi pada siswa SDN Campurejo I Bojonegoro). Skripsi, Universitas Negeri Surabaya.

Maulana, H. 2009. Promosi kesehatan. Jakarta: EGC

Mintarsih. 2007. Pendidikan Kesehatan Menggunakan Booklet dan Poster
Dalam Meningkatkan Pengetahuan dan Sikap Remaja Tentang Kesehatan Reproduksi di Kabupaten Tasikmalaya. Tesis, Universitas Gadjah Mada Yogyakarta.

Ma'munah, M. 2015. Pengaruh Pendidikan Kesehatan Dengan Menggunakan Booklet Terhadap Pengetahuan Nutrisi Ibu Laktasi Di Wilayah Kerja Puskesmas Ciputat Timur. Skripsi, Universitas Islam Negeri Syarif Hidayatullah, Jakarta.

Mihrshahi S, Lisa V, Nicola F, Shreenika W, Inez S, Lisa S. 2017. Evaluation of The Good Start Program: A Healthy Eating And Physical Activity Intervention For Maori And Pacific Islander Children Living In Queensland, Australia. BMC Public Health 17:77

Mardhika Pratiwi. 2014.Hubungan Pengetahuan Ibu dan Status Sosial Ekonomi Dengan Status Gizi Anak Usia 1-3 Tahun (Batita) Di Desa Sangge Kecamatan Klego Kabupaten Boyolali. Jurnal Universitas Muhammadiyah Surakarta

Malik M, Bakir A. 2006. Prevalence of Overweight and Obesity among Children in the United Arab Emirates. Obes. Rev; 8(1):15-20.

Mazarello Paes V, Ong K.K, Lakshman R. 2015. Factors Influencing Obesogenic 
Dietary Intake In Young Children (0-6 years). systematic review of qualitative evidence.http://dx.doi.org/

10.1136/bmjopen-2014-007396) BMJ Open;5:e007396.

Marpaung. 2007. Perilaku Ibu Terhadap Obesitas Pada Anak Usia Sekolah Dasar di SD Pertiwi Kecamatan Medan Barat Tahun 2007. Skripsi Universitas Sumatera Utara, Medan.

Maisaroh. 2013. Gambaran Pengetahuan Ibu yang Mempunyai Balita Tentang Obesitas Pada Balita Di Lingkungan XIX Kelurahan Binjai Kecamatan Medan Denai. Jurnal Akademi Kebidanan Nusantara 2000 Vo.I.

Marlissa W, Emelia. 2015. Perilaku Orang Tua dan Keluarga Terhadap Obesitas Pada Anak Kelas 5 SD di SDN 70 Manado. Jurnal Universitas Sam Ratulangi Manado Vol.3.

Merisya, Eryati Darwin, Detty Iryani. 2014. Hubungan Tingkat Pengetahuan Ibu Tentang Gizi Dengan Kejadian Obesitas anak di SD Islam Al-Azhar 32 Padang. Jurnal Universitas Andalas, Padang Vol.4.

Mustaida., 2014. Efektifitas Pendidikan Kesehatan terhadap Pengetahuan Dan sikap Ibu Dalam Merawat Pasien Anak Diare Di Dua Rumah sakit Di
Wonosobo.Tesis, Universitas Gajah Mada Yogyakarta.

Moch. Dwi Cahyo Saputro.2014. Hubungan Antara Tingkat Pendidikan Orangtua dengan Status Gizi Siswa (Studi pada Siswa SDN Campurejo 1 Bojonegoro). Jurnal Universitas Negeri Surabaya Vol.3.

Nirwana, BA. 2012. Obesitas Anak dan Pencegahannya. Yogyakarta : Medical Book.

Nursalam \& Efendi, F .2008. Pendidikan Dalam Keperawatan. Jakarta : Salemba Medika

Notoatmodjo, S. 2017. Metodologi Penelitian Kesehatan. Jakarta: Rineka Cipta

Notoatmodjo, S. 2010. Metodologi Penelitian Kesehatan. Jakarta: Rineka Cipta.

National Institute of Diabetes and Digestive and Kidney Disease. 2013. Statistic of Diabetes.

http://www.diabetes.niddk.nih.gov/d $\mathrm{m} /$ pubs/statistics.

Ng,M., Flemming, T., Robinson, M., Thomson, B., Greatz,N., Margono, C., Gupta, R. 2014. Global, Regiona, and National Prevalence of Overweight and Obesity in Children and Adults During 1980-2013: a Systematic Analysis for the Global Burden of Disease Study. Europe PMC Funders Group : 766-781. 
Nuryanto, Adriyan P, Niken P, Siti Fatimah M.

2013. Pengaruh pendidikan gizi terhadap pengetahuan dan sikap tentang gizi anak Sekolah Dasar. Jurnal Gizi Indonesia Vol.3.

Usi Lanita. 2015. Pengaruh Pendidikan Kesehatan melalui Short Message Service (SMS) dan Booklet tentang Obesitas Terhadap Pengetahuan dan IMT Remaja Overweight dan Obese di 3 SMA Kota Yogyakarta. Tesis Kesehatan Gizi Universitas Gajah Mada.

Ozguven, Betul E, Ali A, Pinar D. 2010. Evaluation of Nutritional Status in Turkish Adolescent as Related to Gender and Sosioeconomis Status. Journal of Clinical Research in Pediatric Endocrinology;2(3):111-116 DOI: 10.4274/jcrpe.v2i3.111

Onis Md, Blossner M.2010. Prevalence and Trends of Overweight Among Preschool Children In Developing Countries. American Journal of Clinical Nutrition;72:1032-9

Peltzer K, Pengpid S. 2011. Overweigth and Obesity and Assosiated Factors among School-Aged Adolescents in Ghana and Uganda. Diakses 23 Mei 2016. http//www.mdpi.com/journal/ijerph Pakpour, A.H, Yekaninejad, M.S, Chen, H. 2011. Mothers ' perception of obesity in schoolchildren: a survey and the impact of an educational intervention. Journal de Pediatria, 87(2), pp.169174.

Puspita, I. D. 2012. Retensi Pengetahuan, Sikap, dan Perilaku Pasca Pelatihan Gizi Seimbang pada Siswa Kelas 5 dan 6 Di 10 Sekolah Dasar Terpilih Kota Depok Tahun 2012. Tesis Universitas Indonesia, Depok.

Radharani, Luh Rai. 2008. Hubungan Antara Tingkat Pengetahuan Ibu Tentang Obesitas Dengan Cara Pemberian Makan Pada Anak Usia Sekolah. Skripsi Universitas Indonesia, Depok.

Rahmawati, Sudikno. 2008. Faktor Risiko Terhadap Obesitas Pada Orang Dewasa Di Depok, Jawa barat Tahun 2007. Indonesia Journal of Clinical Nutrition Vol. 2.

Roger, V.L., Go, A.S, Lloyd-Jones, D.M., Benjamin, E.J., Berry, J.D., Borden, W.B. 2011, Heart Disease and Stroke Statistics. The American Heart Association, American Heart Association, Circulation (125), e68-e87 Rahmawati, 2009. Hubungan antara Aktivitas Fisik, Frekuensi Konsumsi Makanan Cepat Saji (Fast Food) dan Keterpaparan Media dengan Kejadian Obesitas pada Siswa SD Islam Al-Azhar 
1 Jakarta Selatan. Skripsi. Universitas Indonesia, Depok.

Simamora, R. H. 2009. Buku Ajar Pendidikan dalam Keperawatan. Jakarta: EGC.

Sesdiawan, Mezki. 2013. Perancangan Media

Buku Pop-Up Sebagai Upaya Pencegahan Perilaku Anak Usia 7-12 Tahun Berisiko Obesitas Di Bandung. jurnal Universitas Telkom, Bandung Vol. 2.

Spargo M, Mellis, C. 2014. Childhood obesity and parental perceptions in a rural Australian population: A pilot study.Journal of Pediatrics And Child Health, 50, pp.131-134.

Sukirjo. 2009.Efektifitas Leaflet Sebagai Media Edukasi Untuk Meningkatkan Pengetahuan pasien Hipertensi Perokok: Kajian di RSUD Wates. Skripsi, Universitas Gajah Mada, Yogyakarta.

Syarif D.2011. Obesitas Pada anak dan Permasalahannya. Jakarta. Fakultas Kedokteran Universitas Indonesia.

Schmiege, S.J, Bonnie G.C,Lynn G, Heather A, Kevin C, Gilbert, Amy B. 2016. Identifying patterns of obesity risk behavior to improve pediatric primary care. Journal For Specialists In Pediatrics Nursing , 21, pp.18-28.

Setyowati, L. 2011. Efektifitas media audiovisual pada pendidikan kesehatan personal hygiene terhadap pengetahuan dan sikap siswa sd negeri pusmalang, wukirsari, cangkringan, sleman, yogyakarta.Skripsi, Universitas Gajah Mada,Yogyakarta.

Sari SM, Ismail. 2012. Faktor-Faktor Yang Mempengaruhi Pengetahuan SiswaSiswa Tentang HIV/AIDS di SMIT Negeri Kota Banda Aceh. http://ejournal.uui.ac.id.

Soegih, Wiramiharja. 2009.Obesitas Permasalahan dan Terapi Praktis. Jakarta : Sagung seto.

Sartika, D. 2011. Faktor Risiko Obesitas Pada Anak 5-15 Tahun Di Indonesia. Skripsi, Universitas Indonesia, Depok.

Skouteris, Helen, Marita M, Boyd S, Briony H. 2010. Study Protocol Healthy Eating And Obesity Prevention For Preschoolers: a Randomised Controlled Trial. BMC Public Health, $10: 220$

http://www.biomedcentral.com/1471$2458 / 10 / 220$

Traversa, Amaranta, Daniela A, Alberto B, Daniela M.B, Silvia G, Clara I, Angelo R, Paola D, Andrea P, Lucia D. 2017. Food Safety And Sustainable Nutrition Workshops: Educational Experiences For Primary School Children In Turin Italy. Italian Journal of Food Safety 2017; volume 6:6177 
Jurnal Bidang Ilmu Kesehatan

World Health Organisation (WHO). 2013. Obesity and overweight. http://www.who.int/mediacentre/fact sheets/fs311/en/ diakses pada Juni 2016.

Wijayaningrum, Nugraha T, Inakawati S, Peni H. 2015. The Application of Training Module about School Children's Central Vision Examination for
Increasing Elementary School Teacher's Knowledge and Skill Level to Detect Poor Visual Acuity. Ophtalmol Ina ;41(3):299-304.

Wong, D. L., Hockenberry, E. M., Wilson, D., Winkelstein, M. L., \& P Schwartz. 2009. Buku Ajar : Keperawatan Pediatrik. (A. Hartono, S. Kurnianingsih, \& Setiawan, Eds.) (2nd ed.). Jakarta : EGC. 